\title{
Serving size on nutrition labeling for processed foods sold in Brazil: Relationship to energy value
}

\author{
A porção na rotulagem nutricional de \\ alimentos processados comercializados \\ no Brasil: relação com o valor energético
}

\author{
Nathalie KLIEMANN ${ }^{1}$ \\ Marcela Boro VEIROS \\ David Alejandro GONZÁLEZ-CHICA ${ }^{2}$ \\ Rossana Pacheco da Costa PROENÇA ${ }^{1}$
}

\section{A B S T R A C T}

\section{Objective}

This study aimed to analyze serving sizes declared on food labels with respect to their conformity to Brazilian law, variability among similar foods, and relationship to energy values.

\section{Methods}

Food label information from 24 groups of processed foods was collected in one supermarket in southern Brazil. Declared serving sizes were classified into five groups according to their level of compliance with those recommended by law: $<70 \%$ and $>130 \%$ inadequate and $70-99 \%, 100 \%$ and $101-130 \%$ adequate. Descriptive analyses, Spearman correlations, and Kruskal-Wallis tests were applied.

\section{Results}

A total of 1,953 food products were analyzed, of which $72 \%$ reported serving sizes exactly equal to those recommended, and $14 \%$ fell within the acceptable $60 \%$ range established by law. Even though most foods complied with the law, there was a variation in declared serving sizes among similar foods, with the largest ranges observed for hamburger and meatballs $(364 \mathrm{~g})$. In addition, declared serving sizes were significantly and positively correlated to energy value in most food groups, revealing that smaller serving sizes may be used to report lower energy value.

\footnotetext{
1 Universidade Federal de Santa Catarina, Programa de Pós-Graduação em Nutrição, Núcleo de Pesquisa de Nutrição em Produção de Refeições. R. Eng. Agronômico Andrei Cristian Ferreira, s/n., Trindade, 88040-900, Florianópolis, SC, Brasil. Correspondência para/Correspondence to: RPC PROENÇA. E-mail: <rossana.costa@ufsc.br>.

2 University of Adelaide, Faculty of Health Sciences, School of Medicine. South Australia, Australia.

Support: Coordenação de Aperfeiçoamento de Pessoal de Nivel Superior.
} 


\section{Conclusion}

The $60 \%$ acceptable serving size range established by law may lead to a lack of serving size standardization and significant variability in declared energy values on labels. This can potentially make labels confusing when comparing similar products and thus affect food choices. It is necessary to revise Brazilian law so that serving sizes are standardized among similar foods in order to facilitate healthy food choices.

Keywords: Food choice. Food labeling. Legislation, Food. Nutrition policy. Nutritional facts.

\section{RE S U M O}

\section{Objetivo}

Este estudo objetivou analisar a informação sobre porção na rotulagem nutricional de alimentos processados, considerando as recomendações da legislação brasileira, a variabilidade entre alimentos similares e a sua relação com o valor energético.

\section{Métodos}

Foram coletadas informações sobre a rotulagem nutricional de 24 grupos de alimentos processados disponíveis em um supermercado no sul do Brasil. As porções declaradas foram classificadas em cinco grupos de acordo com a sua adequação às porções recomendadas pela legislação brasileira, sendo $<70 \%$ e $>130 \%$ inadequada e $70-99 \%, 100 \%$ e 101-130\% adequada. Foram conduzidas análises descritivas e de correlação de Spearman, bem como testes de Kruskal-Wallis.

\section{Resultados}

Foram analisados 1953 alimentos industrializados, sendo que 72\% apresentaram porções idênticas às recomendadas e $14 \%$ declararam porções dentro da margem de $60 \%$ de variabilidade permitida pela legislação. Houve grande variabilidade no tamanho da porção declarada entre alimentos similares, com amplitude máxima entre hambúrgueres e almôndegas (364 g). Além disso, observou-se correlação significativa e positiva entre porção e valor energético declarados na maioria dos grupos de alimentos, indicando que porções menores podem estar sendo utilizadas para declarar menor valor energético.

\section{Conclusão}

Concluiu-se que a margem permitida pela legislação para declaração do tamanho da porção nos rótulos de alimentos pode estar levando a uma baixa padronização das porções declaradas entre alimentos similares e a uma variabilidade significativa no valor energético declarado. Como consequência, isso pode gerar rótulos de alimentos confusos e afetar as escolhas alimentares. Dessa forma, faz-se necessária revisão da legislação de rotulagem nutricional, visando uniformizar as porções declaradas nos rótulos e facilitar escolhas alimentares mais saudáveis.

Palavras-chave: Escolha alimentar. Rotulagem de alimentos. Legislação sobre alimentos. Política nutricional. Informação nutricional.

\section{INTRODUCTION}

Evidence shows that higher processed food consumption and larger serving sizes have been related to the development of chronic diseases, especially obesity ${ }^{1-5}$. As a consequence, authors have argued for the need for public policies and programs aimed at the public to promote healthier food choices and more appropriate serving sizes ${ }^{2,3,5,6}$. Dietary guidelines for the public and nutrition labeling have been cited as measures to support the dissemination of nutrition information and promote healthy eating?

The World Health Organization promotes nutrition labeling as an important strategy to encourage healthy food choices for the public ${ }^{8}$ and recommends that it be made mandatory ${ }^{9}$. According to a review conducted by the World Health Organization ${ }^{10}$, nutrition labeling was still voluntary in most of the 74 countries analyzed, although it is increasingly being made mandatory. This review showed that ten countries (including 
developed and developing countries) mandate nutrition labeling and most of these countries require that nutrition information be presented in terms of serving size. These countries include the United States, Canada, Australia, New Zealand and the member countries of Mercosul (Argentina, Brazil, Paraguay and Uruguay).

Brazil and other Mercosul countries require nutrition information per serving to be declared for energy, protein, carbohydrates, total fat, saturated fat, trans fat, dietary fiber, and sodium. Information about the number of servings per package is not mandatory. In these countries, serving size information on nutrition labeling is a recommendation based on usual dietary intake of different foods by the population, adjusted for a balanced diet of 2,000 mil kcal ${ }^{11,12}$. Thus, Brazilian law sets recommended serving sizes in grams or milliliters to be declared on labels for most foods and also requires information about respective household measurements ${ }^{11}$. As a result of this public policy, it is expected that such information will become standardized, allowing for comparisons of similar foods, facilitating food choices, and promoting the intake of appropriate quantities ${ }^{7,11}$.

Nevertheless, Brazilian law allows the serving sizes declared on nutrition labels to vary from $30 \%$ less to $30 \%$ more than the recommended value $^{11}$. Research suggests that a lack of serving size standardization among similar foods may affect the objectives of nutrition labeling, as it complicates food choices ${ }^{6,13-15}$. Studies have suggested that this lack of serving size standardization may be related to the energy density of processed foods ${ }^{16,17}$. According to Monteiro ${ }^{18}$, modern marketing strategies mainly focus on processed food products as these foods are highly profitable for the industry due to their inexpensive ingredients. The use of serving sizes on nutrition labeling may be a part of these sophisticated marketing strategies.

According to the Brazilian household budget survey ${ }^{19}$ and individual food intake data ${ }^{20}$, the purchase and consumption of processed foods have increased, especially among adolescents and adults. As consistent and simple serving size information on nutrition labeling is considered an important strategy to facilitate healthy food choices and intake ${ }^{21}$, it is relevant to analyze how serving sizes are declared on processed food labels in Brazil. Considering the lack of studies in Brazil assessing serving size declaration and the allowed variation by the Brazilian law, the aim of this study was to analyze the serving sizes declared on Brazilian food labels with respect to their conformity to Brazilian law, variability among similar foods and relationship to energy value.

\section{METHODS}

The current descriptive cross-sectional study analyzed the labeling of processed foods available at a Brazilian supermarket. The supermarket was randomly chosen in the city of Florianópolis, the capital of Santa Catarina state, in southern Brazil. It sells a national range of processed foods and belongs to one of the ten largest supermarket chains in the country ${ }^{22}$. Most of the products sold in these stores are similar to those sold by other large supermarket chains throughout the country.

Processed foods are made from substances extracted from whole foods such as the inexpensive parts or remnants of animals, or inexpensive ingredients such as refined starches, sugars, fats, oils, salt, preservatives and other additives. These products (called convenience products) are formulated to be intensely palatable, have a long shelf life and eliminate the need for cooking ${ }^{4}$.

For this study, only prepared and preprepared processed foods were included, according to the classification proposed by Monteiro \& Cannon 4 . This classification was chosen because it enables the inclusion of foods that are becoming an increasingly large part of the Brazilian diet and are related to an increase in chronic diseases ${ }^{19,20,23,24}$. 
We excluded all foods that lacked declared serving sizes in grams or milliliters, as recommended by law. We also excluded all foods that were concentrated, powdered, dehydrated, and/or mixed or that required reconstitution by adding other ingredients since it is not possible to determine exact serving sizes for these food products. Bakery products prepared and packaged by the supermarket itself were also excluded because labeling these products - which are sold with or without protective packaging - is not mandatory in Brazi ${ }^{25}$. Finally, foods with packages lacking serving size information in grams or milliliters were also excluded. The food groups included in this study are shown in Table 1.

Information was collected from all food products available at the supermarket, which were classified into the 24 groups of processed foods included in this study. A previously tested form was used to collect the information reported on food packaging, such as product identity (product, commercial name, flavor, brand, net quantity) and information on nutrition labeling (serving size by

Table 1. Description of the recommended serving sizes, declared serving sizes, and declared energy values on the labels of the processed foods ( $n=1953)$, Florianópolis, Brazil, 2011.

\begin{tabular}{|c|c|c|c|c|c|c|c|c|}
\hline \multirow{2}{*}{ Food group } & \multirow{2}{*}{$\mathrm{n}$} & \multirow{2}{*}{$\begin{array}{l}\text { Serving size } \\
\text { as stated in } \\
\text { the law }{ }^{1} \\
\text { ( } \mathrm{g} \text { or } \mathrm{mL})\end{array}$} & \multicolumn{3}{|c|}{ Declared serving size ( $\mathrm{g}$ or $\mathrm{ml}$ ) } & \multicolumn{2}{|c|}{$\begin{array}{l}\text { Declared energy } \\
\text { value (kcal) }\end{array}$} & \multirow{2}{*}{$\begin{array}{l}\text { Declared } \\
\text { serving size vs } \\
\text { declared } \\
\text { energy value } \\
\text { (r) }\end{array}$} \\
\hline & & & $\begin{array}{c}\text { size as stated } \\
\text { in the law }{ }^{2} \\
(\%)\end{array}$ & $M^{3}$ & Min - Max & $M^{3}$ & Min - Max & \\
\hline Dry pasta & 67 & 80 & 6.0 & 85 & $30-109$ & 364.0 & $136-489$ & $0.78^{* * *}$ \\
\hline Fresh pasta & 48 & 100 & 66.6 & 100 & $50-160$ & 275.0 & $132-385$ & 0.27 \\
\hline Pancake batter & 23 & 30 & 21.0 & 30 & $30-60$ & 90.0 & $47-235$ & $0.49^{* *}$ \\
\hline Pizza dough/frozen pastries & 22 & 40 & 59.1 & 40 & $26-120$ & 120.0 & $73-468$ & $0.85^{* * *}$ \\
\hline Bread/Frozen cheese bread & 108 & 50 & 88.0 & 50 & $40-75$ & 126.0 & $83-303$ & $0.36^{* * *}$ \\
\hline Salted crackers/toasts & 118 & 30 & 65.3 & 30 & $21-30$ & 119.0 & $90-200$ & $0.4^{* * *}$ \\
\hline $\begin{array}{l}\text { Pre-fried and/or frozen tubers } \\
\text { and cereals }\end{array}$ & 11 & 85 & 81.8 & 85 & $70-100$ & 123.0 & $88-228$ & 0.33 \\
\hline Breakfast cereals ( $\leq 45 \mathrm{~g}$ cup) & 22 & 30 & 90.9 & 30 & $20-30$ & 110.0 & $70-120$ & $0.5^{* *}$ \\
\hline Breakfast cereals ( $>45 \mathrm{~g}$ cup) & 39 & 40 & 100.0 & 40 & -6 & 158.0 & 104-192 & 0.0 \\
\hline Snacks (chips/puffs/popcorn) & 138 & 25 & 87.7 & 25 & $10-40$ & 121.0 & $48-170$ & $0.3^{* * *}$ \\
\hline Farofa\# & 6 & 35 & 100.0 & 35 & -6 & 142.5 & $133-155$ & 0.0 \\
\hline Cakes & 55 & 60 & 74.5 & 60 & $30-60$ & 219.0 & $96-275$ & $0.74^{* * *}$ \\
\hline $\begin{array}{l}\text { Dairy drinks }{ }^{+} / \text {yogurt/fermented } \\
\text { milk }^{+}\end{array}$ & 186 & 200 & 34.9 & 180 & $75-300$ & 112.5 & $38-269$ & $0.53^{* * *}$ \\
\hline Cheese $1 \mathbf{\wedge}$ & 45 & 50 & 31.1 & 40 & $30-60$ & 64.0 & $28-123$ & 0.25 \\
\hline Cheese $\mathbf{2}^{\mathbf{4}}$ & 184 & 30 & 94.6 & 30 & $20-120$ & 99.5 & $19-400$ & 0.01 \\
\hline Grated cheese/pate & 40 & 10 & 65.0 & 10 & $10-100$ & 44.0 & $13-299$ & $0.84^{* * *}$ \\
\hline Dairy desserts & 20 & 120 & 0.0 & 105 & $40-200$ & 128.0 & $50-341$ & 0.21 \\
\hline Hamburgers/meatballs & 25 & 80 & 68.0 & 80 & $56-420$ & 149.0 & $64-534$ & $0.73^{* * *}$ \\
\hline Meat pastries & 49 & 130 & 61.2 & 130 & $30-275$ & 245.0 & $28-347$ & $0.8^{* * *}$ \\
\hline Processed nuts & 31 & 15 & 87.1 & 15 & $15-25$ & 87.0 & $47-121$ & $0.58^{* * *}$ \\
\hline Chantilly/candy & 106 & 20 & 84.0 & 20 & $2-40$ & 79.0 & $4-149$ & $0.58^{* * *}$ \\
\hline Chocolates/sprinkles & 181 & 25 & 69.2 & 25 & $10-41$ & 131.0 & $40-390$ & $0.68^{* * *}$ \\
\hline Cookies & 275 & 30 & 90.9 & 30 & $14-100$ & 143.0 & $46-362$ & $0.37^{* * *}$ \\
\hline Ice cream/ice lolly & 154 & 60 & 75.2 & 60 & $40-90$ & 114.0 & $36-247$ & $0.42^{* * *}$ \\
\hline
\end{tabular}

Note: +Serving size in ml; \#Farofa is a toasted manioc flour mixture but maize flour is used sometimes and flavors vary; ${ }^{\mathbf{A} C h e e s e} 1$ : cottage cheese, petit-suisse and low fat ricotta, and cream cheese; ${ }^{\mathbf{A}}$ Cheese 2 : ricotta, semi hard, white, soft, and cream cheese. ${ }^{1}$ Reference values from Brazilian law; ${ }^{2}$ Declaration of the exact serving size as stated in the law $(\mathrm{g} / \mathrm{ml}) ;{ }^{3}$ Median; ${ }^{4}$ Highest and lowest observations; ${ }^{5}$ Spearman correlation between declared serving size and declared energy value per serving; ${ }^{-6}$ Serving sizes equal to those recommended for all food products. ${ }^{* *} p<0.01{ }^{* * *} p<0.001$. 
weight and energy per serving in kcal). Information on the packages of identical products in different sizes was collected separately, as the serving size was different for each product. Trained dieticians collected the data in August 2011. The supermarket's manager authorized the research.

The collected data were entered into two separate databases and were subsequently checked for errors and validated in EpiData ${ }^{\circledR}$ version 3.1 (EpiData Association, Odense, Denmark).

The processed food products were divided into 24 groups, in accordance with Brazilian law. These 24 groups were comprised of similar processed foods with the same serving size recommended by law. Central tendency and dispersion (minimum and maximum) measurements were presented for the declared serving sizes and declared energy values per serving in each food group. Percentages of products that declared serving sizes equal to those recommended by law $(\mathrm{g} / \mathrm{ml})$ were also calculated. Spearman correlations between declared serving sizes and declared energy values were reported for each food group, as the data was not normally distributed. In addition, declared serving sizes were classified into five groups according to their level of conformity to Brazilian law ${ }^{11}$, using the criteria presented in Table 2.

To analyze the relationships between the conformity of the serving sizes to Brazilian law ${ }^{11}$ and declared energy values per serving, analyses of variances were applied using the Kruskal-Wallis test, as the variances were found by the Bartlett test to be significantly different. Post-hoc tests were performed using Dunn's procedure. Values of $p<0.05$ were considered statistically significant. The data analyses were done in the Stata version 11.0 statistical program (StataCorp, CollegeStation, TX, United States).

\section{RE S U L T S}

Information was collected from the labels of 1,957 processed foods. However, four fresh pasta products were excluded because they did not provide serving size information. Table 1 presents the variability of serving sizes ( $\mathrm{g}$ or $\mathrm{ml}$ ) and energy values per serving declared on the labels of the 1,953 processed foods analyzed. Medians were included because the data were not symmetrically distributed. In the serving size analysis, serving size standardization (when all food products have declared the exact serving sizes provided by law) was found in only two food groups: breakfast cereals (>45 grams per cup) and farofa (toasted manioc flour mixture but maize flour is used sometimes and flavours vary). The remaining 22 food groups showed clear variations in declared serving sizes for similar food products, with the largest ranges observed for hamburger and meatballs ( $364 \mathrm{~g}$ ); meat pastries ( $245 \mathrm{~g}$ ); and dairy drinks, yogurt and fermented milk (225 g).

The dairy desserts group had no products with declared serving sizes equal to those

Table 2. Classification of the declared serving sizes on food labels according to their level of conformity to Brazilian law recommendations. Florianópolis, Brazil, 2011.

\begin{tabular}{lll}
\hline $\begin{array}{l}\text { Level of conformity to } \\
\text { recommended serving sizes }\end{array}$ & Meaning & $\begin{array}{c}\text { Compliance with } \\
\text { Brazilian law }^{1}\end{array}$ \\
\hline$<70 \%$ & Serving sizes smaller than $70 \%$ of the recommended serving size $(\mathrm{g} / \mathrm{mL})$. & Noncompliant \\
$70-99 \%$ & Serving sizes up to $30 \%$ smaller than recommended serving size $(\mathrm{g} / \mathrm{mL})$. & Compliant \\
$100 \%$ & Serving sizes equal to those recommended $(\mathrm{g} / \mathrm{mL})$. & Compliant \\
$101-130 \%$ & Serving sizes up to $30 \%$ larger than recommended serving size $(\mathrm{g} / \mathrm{mL})$. & Compliant \\
$>130 \%$ & Serving sizes larger than $130 \%$ of the recommended serving size $(\mathrm{g} / \mathrm{mL})$. & Noncompliant \\
\hline
\end{tabular}

Note: ${ }^{1}$ Reference values from Brazilian law. 
recommended by law. Four groups had less than $35 \%$ of their products conforming to the recommended serving sizes: dry pasta; pancake batter; cheese 1; and dairy drinks, yogurt and fermented milk. In terms of declared energy value, foods with greater variation in declared serving size also showed a greater energy value range, such as hamburger and meatballs (470 kcal); meat pastries (319 kcal); and dairy drinks, yogurt and fermented milk (231 kcal). Spearman correlations assessed the relationship between declared serving size and declared energy value in each food group. The results showed a positive and significant correlation between these variables for most food groups. A strong relationship was found for hamburger and meat pastries $\left(r_{s}>0.7\right)$, and a medium relationship was found for dairy drinks, yogurt and fermented milk $\left(r_{s}=0.53\right)$. However, no correlation was found between declared serving size and declared energy value for fresh cheeses ( 1 and 2 ), breakfast cereals ( $>45$ g cup), farofa or dairy desserts.

In the analysis of the conformity of serving sizes to Brazilian law, it was found that $72.5 \%$ (95\% Confidence Interval $[95 \% \mathrm{Cl}] 70.3 ; 74.3$ ) of the processed foods declared serving sizes equal to those recommended. Among the foods that did not report the exact recommended serving sizes, $10.1 \%(95 \% \mathrm{Cl} 8.7 ; 11.5)$ and $4.0 \%(95 \% \mathrm{Cl}$ $3.0 ; 4.8)$ were still appropriate according to the law since they had conformities of $70-99 \%$ and $101-130 \%$, respectively. The other foods did not conform to the law, with $9.3 \%(95 \% \mathrm{Cl} 8.0 ; 10.6)$ having smaller serving sizes and $4.1 \%(95 \% \mathrm{Cl}$ $3.2 ; 5.0$ ) having larger serving sizes than recommended.

Table 3 shows that median declared energy per serving differed significantly in terms of serving size compliance with Brazilian law $(p<0.001)$. Post-hoc analysis revealed statistically significant differences in declared energy values between most pairwise comparisons $(p<0.001)$, except between the $70-99 \%$ and $100 \%$ and between the $101-130 \%$ and $>130 \%$ groups.

\section{DISCUSS ION}

This is the first study to analyze the serving sizes declared on processed food labels in Brazil with respect to their conformity to the law, variability, and relationship to energy values. The study showed that even though most processed foods conformed with the law, there was variability in the declaration of serving sizes among similar processed foods, and this was positively related to the declared energy values in most food groups.

The lack of standardization in declaring serving sizes on the nutrition labels of similar food products was reported in another Brazilian study, which analyzed the labels on dairy drinks, yogurt, and fermented milk sold in the Southeast region of Brazil. This study found serving sizes ranging

Table 3. Relationship between the level of compliance of the declared serving size with the Brazilian law and the declared energy value per serving of the processed foods $(n=1,953)$. Florianópolis, Brazil, 2011.

\begin{tabular}{|c|c|c|c|c|c|c|c|}
\hline \multirow{2}{*}{ Level of conformity to recommended serving sizes ${ }^{1}$} & \multirow{2}{*}{$\mathrm{n}$} & \multirow{2}{*}{$\%$} & \multicolumn{2}{|c|}{ Declared energy value per serving ( $\mathrm{kcal}$ ) } & \multicolumn{3}{|c|}{ Statistical test ${ }^{4}$} \\
\hline & & & Median $^{2}$ & $\mathrm{IQR}^{3}$ & $d f$ & $H$ & $p$-value \\
\hline$<70 \%$ & 182 & 9.3 & 84.5 & $(56-114)$ & 4 & 281.7 & $<0.001$ \\
\hline $70-99 \%$ & 199 & 10.1 & 116.0 & $(96-139)$ & & & \\
\hline $100 \%$ & 1414 & 72.5 & 125.0 & $(100-144)$ & & & \\
\hline $101-130 \%$ & 77 & 4.0 & 280.0 & $(158-380)$ & & & \\
\hline$>130 \%$ & 81 & 4.1 & 204.0 & $(138-269)$ & & & \\
\hline
\end{tabular}

Note: ${ }^{1}$ Reference values from Brazilian law; ${ }^{2}$ Post hoc analysis showed that declared energy values were statistically different between most groups, except the pairwise comparison between the $70-99 \%$ and $100 \%$ levels of conformity and between $101-130 \%$ and $>130 \%$ levels of conformity; ${ }^{3} \mathrm{QQR}=$ Interquartile Range; ${ }^{4}$ Kruskal-Wallis test; $d f$ : Degree of freedom 
from $100 \mathrm{~g}$ to $200 \mathrm{~g}$, even though the serving size recommended by law ${ }^{11}$ for these foods is $200 \mathrm{~g}^{17}$. Our study found an even larger range for these foods - $75 \mathrm{~g}$ to $300 \mathrm{~g}$. Similar results were found in the studies cited below, which were conducted in other countries where nutrition label information is also declared by serving size. In Australia, 1,070 processed foods were analyzed, and serving sizes declared on snacks were found to range from $18 \mathrm{~g}$ to $100 \mathrm{~g}$, demonstrating low uniformity ${ }^{13}$. Vartanian \& Sokol ${ }^{26}$ assessed 3,344 processed foods in Australia and found variability in serving size information for foods within the same group and belonging to the same brand. Studies in the United States show that serving sizes on labels can vary from $50 \%$ to $200 \%$ of the reference serving size defined by the food and drug administration ${ }^{27,28}$. A study in the United Kingdom found that serving sizes on processed meat pie labels ranged from $138 \mathrm{~g}$ to $300 \mathrm{~g}$, which may complicate product comparison, especially considering that British consumers view labeling as a tool for making quick food choices ${ }^{29}$.

Moreover, the results of a study conducted by Anderson et al. ${ }^{29}$ emphasize that a lack of serving size standardization compromises the comparability of processed foods when only the information per serving is available. Thus, this may affect food choices that are based on food label information, undermining the goals of nutrition labeling ${ }^{13,17,28}$. Serving size variability may also lead consumers to have misconceptions about a food's nutritional composition, which is a violation of consumer rights as guaranteed by Article 31 of the Brazilian Consumer Defense Code $^{30}$ and "Codex Alimentarius guidelines" 10 . Serving size variability may also affect people's consumption, as suggested by a study conducted by Dallas et al. ${ }^{31}$, which explored the effect of serving sizes on the amount of food people consume.

Serving size variability was positively related to energy value. This relationship supports the hypothesis by Walker et al. ${ }^{13}$ that smaller serving sizes on labels may be used to highlight the foods' nutritional characteristics that are perceived as favorable by consumers (for example, lower energy value). It is likely that consumer perceive foods reporting lower caloric values on their labels to be healthier ${ }^{32}$. This fact becomes even more relevant when one considers that energy value is one of the nutrition label items most looked at by Brazilians as well as by consumers in Europe and India ${ }^{33-35}$. In addition, the analyses of serving size compliance with the law showed that products reporting serving sizes up to $30 \%$ lower than the recommended ones (classified as adequate by the law) also reported smaller energy values than those that declared the exact recommended serving size. Even though this difference was not significant, it may suggest that allowing the serving size to vary from $30 \%$ less to $30 \%$ more than the recommended value may lead some food manufacturers to report lower energy values.

Groups of processed foods with high serving size variability also had high variability in terms of declared energy values. Similarly, a study conducted in Australia found great variations in declared energy values and serving sizes on snack foods and confectionery products ${ }^{36}$. This fact might make the comparability of similar foods even more complex and consequently, affect food choices. The lack of information about the number of serving sizes per package, which is not mandated by Brazilian law, might also increase confusion among consumers with respect to serving size. It has been pointed out that people have difficulty understanding that serving size information on labels does not always represent a package's total content $35,37,38$, which can potentially lead to the underestimation of energy consumption.

The results found in this study become even more relevant when one considers that serving size information problems appear for foods with high levels of energy, sugar, saturated fat, trans fat and sodium, as well as low levels of fiber (i.e. processed food products). Thus, our research also suggests that allowing a $60 \%$ variability in declared serving sizes may also lead to great variability for other nutrients, such as saturated fat, trans fat, and sodium. Considering that the consumption of these nutrients is associated with the development of several non- 
communicable diseases ${ }^{1}$, clear food labeling is essential to promoting healthy food choices and preventing harmful effects ${ }^{39}$. Nevertheless, the Brazilian law allows food companies to claim "zero trans fat" or "trans fat free" on food packaging if the amount of trans fat per serving is less than $0.2 \mathrm{~g}^{40}$. One study analyzed 2,020 food products in Brazil, aiming to assess the relationship between serving size and trans fat on food labels. The results showed that more than $40 \%$ of the breads, biscuits, pastries and sweets that claimed "zero trans-fat" and declared an adequate serving size $(100 \%, 70-99 \%$, or $101-130 \%$ adequate) were classified as false negatives. This means that these products had trans fat in their ingredient list, but the trans fat content per serving size was lower than 0.2 , so they were allowed to claim "zero trans fat" ${ }^{\prime \prime}$. Since Brazilians tend to consume these products in amounts larger than the serving sizes declared on their food labels and since trans fat content is not clearly and visibly shown on the food labels, consumers may be underestimating their trans fat consumption ${ }^{41}$. In addition a research study found great variability in the serving sizes and sodium content reported on the labels of processed snack foods $(n=2,945)$ sold in Brazil ${ }^{42}$. Therefore, the acceptable range of $60 \%$ established by law seems to be excessive and may be leading to great variability in the serving sizes and nutritional information declared on labels and potentially to unhealthy food choices.

It should also be noted that even though Brazilian law ${ }^{11}$ allows for $60.0 \%$ variability in declared serving sizes, our study found that $13.4 \%$ of the foods analyzed still declared serving sizes that did not conform to the law. This result is in line with the findings of Kraemer et al. ${ }^{42}$, who analyzed 2,945 processed foods sold in Brazil and found that $13.0 \%$ did not comply with the recommended serving sizes. This study also found similar percentages of products reporting serving sizes smaller (9.5\%) and larger (4.3\%) than those recommended by law. Moreover Camara et al. ${ }^{43}$ observed a high level of noncompliance with the law when analyzing the academic literature in a narrative review article about nutrition labeling in Brazil between 1987 and 2004. Therefore, it is evident that greater oversight is needed for the information made available to consumers on food packaging.

A review of the Brazilian legislation on nutrition label serving sizes is required, even though the use of nutrition information in food choices and its effect on consumers' health is still controversial $29,35,44$. Nutrition labeling enables access to information, which is a consumer right, and its improvement is considered important to strengthening consumers' ability to analyze and make decisions about food ${ }^{44}$. However, research also emphasizes that it is essential to teach Brazilians on how to interpret nutrition labels so that this information can play a role in facilitating healthy food choices $^{33}$. A recent study has also emphasized the need for updating the reference energy density used to calculate the recommended serving sizes per food product for the Brazilian nutrition labeling law ${ }^{14}$. This study analyzed 2,072 food products available in Brazil and found that the average energy density reported on these foods differed from the reference energy density used for calculating the recommended serving sizes.

One potential limitation of this study was that it used nutrition labels to determine products' energy values, without running chemical analyses. However, the study considered that consumers only have access to what is reported on packaging, so the accuracy of such information should be ensured by the manufacturer and tested for compliance with the law. Another potential limitation was the inclusion of products at a single store. However, since the store belongs to a large chain, most of the products sold by this chain are also sold by other chains and stores throughout the country, so this fact is not likely to affect the study's external validity.

\section{CONCLUSION}

Nutrition labeling by serving size has emerged as an important strategy for promoting healthy food choices. In Brazil such information 
serves an even broader purpose, as it is considered by the public to be an intake recommendation. However, it seems that this policy needs to be improved so that it can meet its goals. The results of this study suggest revisions and improvements to Brazilian law that may lead to the discussion of other laws on serving sizes.

It is evident that the declared serving sizes for processed foods differ from those recommended by law, which can cause potentially confusing labels when comparing similar foods when only the information per serving is available. The serving size range established by the Brazilian law might be leading to a lack of serving size standardization and significant variability in declared energy value on labels among similar food products, and therefore needs to be revised. It is also evident that oversight needs to be improved for nutrition information made available to consumers on food packaging. Furthermore, studies are needed to assess labeling information and especially, to determine the best way to declare such information.

Moreover, it is important for nutritionists, dietitians, and healthcare professionals to teach patients and help them to understand serving sizes on labels. Public health campaigns using the mass media can also be helpful in educating the public about how to use nutrition labeling when making food choices.

\section{COLABORATORS}

N KLIEMANN made a substantial contribution to study design, data collection and analysis, manuscript writing and approval of the final version. MB VEIROS and RPC PROENÇA made a substantial contribution to study design, manuscript writing and approval of the final version. DA GONZÁLEZ-CHICA made substantial contribution to data analysis, manuscript writing and approval of the final version.

\section{REFERENCES}

1. World Health Organization. Global strategy on diet, physical activity and health. Geneva: WHO; 2004.
2. Piernas C, Popkin BM. Food portion patterns and trends among U.S. children and the relationship to total eating occasion size, 1977-2006. J Nutr. 2011; 141(6):1159-64.

3. Malik VS, Willett WC, Hu FB. Global obesity: Trends, risk factors and policy implications. Nat Rev Endocrinol. 2013; 9(1):13-27.

4. Monteiro CA, Cannon G. The impact of transnational "big food" companies on the south: A view from Brazil. Plos Med. 2012; 9(7):e1001252.

5. Young LR, Nestle M. Reducing portion sizes to prevent obesity a call to action. Am J Prev Med. 2012; 43(5):565-8.

6. Kliemann N, Kraemer MVS, Silveria BM, Gonzalez-Chica DA, Proença RPC. Tamanho da porção e gordura trans: os rótulos de alimentos industrializados brasileiros estão adequados? Demetra. 2015; 10(1):43-60.

7. Ministério da Saúde. Cadernos de Atenção Básica: obesidade; 2006 [acesso 2013 mar 1]. Disponível em: http://189.28.128.100/nutricao/docs/geral/doc_ obesidade.pdf/

8. World Health Organization. Follow-up to the political declaration of the high-level meeting of the general assembly on the prevention and control of non-communicable diseases. Geneva: WHO; 2013.

9. Food and Agriculture Organization of the United Nations. Codex alimentarius: Guidelines on nutrition labelling CAC/GL 2-1985. Rome: FAO; 2015.

10. World Health Organization. Nutrition labels and health claims: The global regulatory environment. Geneva: WHO; 2004.

11. Brasil. Ministério da Saúde. Agência Nacional de Vigilância da Saúde. Resolução RDC n³59, de 23 de dezembro de 2003. Aprova regulamento técnico de porções de alimentos embalados para fins de rotulagem nutricional. Brasília: Ministério da Saúde; 2003.

12. Grupo Mercado Comum. Resolução n 44/03, de 10 de dezembro de 2003. Aprova o regulamento técnico do Mercosul para rotulagem nutricional de alimentos embalados. Montevidéu: GMC; 2003.

13. Walker KZ, Woods JL, Rickard CA, Wong CK. Product variety in Australian snacks and drinks: How can the consumer make a Healthy Choice? Public Health Nutr. 2008; 11(10):1046-53.

14. Kliemann N, Veiros MB, Gonzalez-Chica DA, Proenca RPC. Reference serving sizes for the brazilian population: An analysis of processed food labels. Rev Nutr. 2014; 27(3):329-41.

15. Haskelberg $H$, Neal B, Dunford E, Flood $V$, Rangan $A$, Thomas $B$, et al. High variation in manufacturerdeclared serving size of packaged discretionary foods in Australia. Br J Nutr. 2016; 115(10):1810-8. 
16. Drewnowski A, Maillot M, Darmon N. Should nutrient profiles be based on $100 \mathrm{~g}, 100 \mathrm{kcal}$ or serving size? Eur J Clin Nutr. 2009; 63(7):898-904.

17. Grandi AZ, Rossi DA. Evaluation of mandatory nutritional information on labels of fermented dairy products available at the market. Rev Inst Adolfo Lutz. 2010; 69(1):62-8.

18. Monteiro CA. Nutrition and health. The issue is not food, nor nutrients, so much as processing. Public Health Nutr. 2009; 12(5):729-31.

19. Instituto Brasileiro de Geografia e Estatística. Pesquisa de Orçamentos Familiares 2008-2009: despesas, rendimento e condições de vida. Rio de Janeiro: IBGE; 2010 [acesso 2014 jul 2]. Disponível em: http://www.ibge.gov.br/home/estatistica/ populacao/condicaodevida/pof/2008_2009/

20. Instituto Brasileiro de Geografia e Estatística. Pesquisa de Orçamentos Familiares 2008-2009: análise do consumo alimentar pessoal no Brasil [acesso 2014 mar 1]. Disponível em: http://www. ibge.gov.br/home/estatistica/populacao/condicao devida/pof/2008_2009_analise_consumo/

21. Kerr MA, McCann MT, Livingstone MBE. Food and the consumer: Could labelling be the answer? Proc Nutr Soc. 2015; 74(2):158-63.

22. Brasil. Associação Brasileira de Supermercados. Ranking ABRAS 2013. [acesso 2013 jul 2]. Disponível em: http://www.abrasnet.com.br/clipping. php? area $=20 \&$ clipping $=35850 /$

23. World Health Organization. Diet, nutrition and prevention diseases. Geneva: WHO; 2003.

24. Monteiro CA, Levy RB, Claro RM, de Castro IRR, Cannon $\mathrm{G}$. Increasing consumption of ultra-processed foods and likely impact on human health: Evidence from Brazil. Public Health Nutr. 2011; 14(1):5-13.

25. Brasil. Ministério da Saúde. Agência Nacional de Vigilância da Saúde. Resolução RDC n³60, de 23 de dezembro de 2003. Aprova regulamento técnico sobre rotulagem nutricional de alimentos embalados, tornando obrigatória a rotulagem nutricional. Brasília: Ministério da Saúde; 2003.

26. Vartanian LR, Sokol N. Serving-size information on nutrition labels in Australia. Aust Nz J Publ Heal. 2012; 36(5):493-4.

27. Bryant R, Dundes L. Portion distortion: A study of college students. J Consum Aff. 2005; 39(2):399-408.

28. United States Department of Agriculture. Serving Sizes in the food guide pyramid and on the nutrition facts label: What's different and why? Washington (DC): USDA; 2014.

29. Anderson AS, Barton K, Craigie A, Freeman J, Gregor A, Stead M, et al. Exploration of adult food portion size tools. Edinburgh: NHS Health Scotland; 2008.

30. Brasil. Código de proteção e defesa do consumidor. Lei $n^{\circ} 8.078$, de 11 de setembro de 1990. Dispõe sobre a proteção do consumidor e dá outras providências. Brasília; 1990.

31. Dallas SK, Liu PJ, Ubel PA. Potential problems with increasing serving sizes on the nutrition facts label. Appetite. 2015; 95:577-84.

32. Steenhuis IHM, Vermeer WM. Portion size: Review and framework for interventions. Int J Behav Nutr Phy. 2009; 6:58.

33. Monteiro RA, Coutinho JG, Recine E. Usage of food and beverage labels by supermarket shoppers in Brasilia, Brazil. Rev Panam Salud Publ. 2005; 18(3):172-7.

34. Singla M. Usage and understanding of food and nutritional labels among Indian consumers. Br Food J. 2010; 112(1):83-92.

35. Gregori D, Ballali S, Vogele C, Gafare CE, Stefanini G, Widhalm K. Evaluating food front-of-pack labelling: A pan-European survey on consumers' attitudes toward food labelling. Int J Food Sci Nutr. 2014; 65(2):177-86.

36. Watson WL, Kury A, Wellard L, Hughes C, Dunford E, Chapman K. Variations in serving sizes of Australian snack foods and confectionery. Appetite. 2015; 96:32-7.

37. Pelletier AL, Chang WW, Delzell JE, McCall JW. Patients' understanding and use of snack food package nutrition labels. J Am Board Fam Pract. 2004; 17(5):319-23.

38. Lando AM, Lo SC. Single-larger-portion-size and dual-column nutrition labeling may help consumers make more healthful food choices. J Acad Nutr Diet. 2013; 113(2):241-50.

39. Hissanaga VM, Proença RPC, Block JM. Trans fatty acids in Brazilian food products: A review of aspects related to health and nutrition labeling. Rev Nutr. 2012; 25(4):517-30.

40. Proenca RPC, Silveira BM. Intake recommendations and labeling of trans fat in processed foods in Brazil: Analysis of official documents. Rev Saúde Pública 2012; 46(5):923-8.

41. Kraemer MVD, Machado PP, Kliemann N, Chica DAG, Proenca RPC. The brazilian population consumes larger serving sizes than those informed on labels. Br Food J. 2015; 117(2):719-30.

42. Kraemer MV, Oliveira RC, Gonzalez-Chica DA, Proenca RPC. Sodium content on processed foods for snacks. Public Health Nutr. 2016; 19(6):967-75.

43. Camara MCC, Marinho CLC, Guilam MC, Braga AMCB. Academic production on food labeling in Brazil. Rev Panam Salud Publ. 2008; 23(1):52-8.

44. Lachat C, Tseng M. A wake-up call for nutrition labelling. Public Health Nutr. 2013; 16(3):381-2.

Received: February 3, 2016 Final version: April 25, 2016 Approved: May 16, 2016 